\title{
EVA JAKO KLUCZOWY ELEMENT STRATEGII WZROSTU WARTOŚCI FIRMY - ANALIZA POLSKIEGO SEKTORA BANKOWEGO
}

\section{Wstęp}

Zagadnienia związane $\mathrm{z}$ tematyką zarządzania wartością firmy (value-based management - VBM) już od dłuższego czasu wzbudzają coraz większe zainteresowanie zarówno teoretyków, jak i praktyków zarządzania. W ciągu ostatnich dwóch dekad setki firm wdrożyło systemy VBM. Wśród nich można wskazać przedsiębiorstwa zagraniczne (np. Coca-Cola, Hewlett Packard, T-Mobile, Royal Dutch Shell, Lloyds Bank) oraz polskie (np. PKN Orlen, KGHM Polska Miedź, Grupa Tauron, Zakłady Azotowe Kędzierzyn SA, Katowicki Holding Węglowy SA). Powodem takiego stanu rzeczy jest przede wszystkim rosnąca rola inwestorów instytucjonalnych, którzy wymagają, aby kadra zarządzająca spółki koncentrowała się głównie na kreowaniu wartości dla właścicieli kapitału. Ze względu na fakt, iż trudno jest kontrolować to, czego nie można zmierzyć, systemy VBM wymagają wykorzystania miernika tworzenia wartości ekonomicznej, który umożliwi powiązanie interesów właścicieli firmy z celami zarządu oraz kadry menedżerskiej średniego i niższego szczebla, a przez to w efekcie końcowym przyczyni się do wzrostu wartości przedsiębiorstwa.

Celem niniejszego opracowania jest zbadanie poziomu kreowanej wartości przez wybrane banki notowane na Giełdzie Papierów Wartościowych w Warszawie. Badania przeprowadzone na próbie 12 banków mają charakter ilościowy i są oparte na analizie bankowej ekonomicznej wartości dodanej, jej relacji do kapitału zainwestowanego oraz korelacji pomiędzy tworzoną wartością a stopą zwrotu $\mathrm{z}$ akcji na przestrzeni ostatnich 10 lat.

\section{Zarys koncepcji zarządzania wartością przedsiębiorstwa}

Tradycyjne mierniki oceny efektywności funkcjonowania przedsiębiorstwa często odnosiły się do zysku, który jest kryterium dość łatwym do zrozumienia zarówno w kręgach akcjonariuszy, jak i wśród kadry menedżerskiej oraz pracowników. Tymczasem zysk jako kategoria księgowa charakteryzuje się wielo-

\footnotetext{
* Asystent, Katedra Zarządzania Przedsiębiorstwem, Wydział Zarządzania UŁ.
} 
ma wadami ${ }^{1}$, a jego maksymalizacja wcale nie musi wiązać się ze zwiększaniem wartości firmy, którą - ze względu na rosnącą presję ze strony rynków kapitałowych - coraz częściej przyjmuje się za miarę sukcesu danej organizacji. Wobec tego wskazane jest zwrócenie uwagi na fakt, iż nie należy postrzegać wartości przedsiębiorstwa tylko i wyłącznie przez pryzmat zysków księgowych, ale także z perspektywy efektywności wykorzystania kapitału oraz jego kosztu. Warto przytoczyć w tym miejscu słowa J. Jeżaka, który wskazuje, iż „myślenie o wartości musi łączyć ze sobą [...] dwa tak ważne obszary zarządzania, jak strategia i finanse. To scalenie jest niezbędne na wszystkich poziomach zarządzania strategicznego i operacyjnego, przy formułowaniu strategii wzrostu wartości, a także przy jej realizowaniu i kontroli”’2. W związku z powyższym zarówno akcjonariusze, jak i menedżerowie potrzebowali nowego układu odniesienia, który stanowiłby pomost pomiędzy wymaganiami inwestorów, budżetem firmy oraz wynikami operacyjnymi i wyceną giełdową.

Mimo, iż literatura podaje szerokie spektrum definicji zarządzania wartością firmy, zdaniem autora niniejszego artykułu, najciekawsze podejście w tym zakresie zaprezentowali K. Pniewski oraz B. Bartoszewicz, którzy zdefiniowali VBM jako koncepcję pozwalającą „uporządkować całość spraw kształtujących wartość firmy oraz zaprojektować i wdrożyć mechanizmy wpływania na jej wzrost [...]. Pozwala ona również przekładać nadrzędne cele wzrostu wartości na konkretne działania organizacji i motywować pracowników do podejmowania odpowiednich decyzji",3.

Całościowy schemat przedstawiający ustrukturyzowane podejście do zarządzania wartością firmy został przedstawiony na rysunku 1 . Obrazuje on w jaki sposób tworzenie wartości ekonomicznej oraz jej komunikacja przekładają się na wartość rynkową przedsiębiorstwa. Zdaniem specjalistów firmy doradczej Deloitte prawidłowo skonstruowany system VBM powinien określać przede wszystkim następujące cztery kwestie ${ }^{4}$ :

${ }^{1}$ Do wad zysku księgowego jako kryterium oceny efektywności funkcjonowania przedsiębiorstwa można zaliczyć: (1) memoriałowy sposób liczenia; (2) sposób i termin zawiązywania i rozwiązywania rezerw, który często wywiera istotny wpływ na wielkość osiąganego zysku; (3) wyłączenie z obliczeń wydatków dotyczących przyszłych inwestycji; (4) brak uwzględnienia skali działania przedsiębiorstwa, a także możliwości efektywniejszego wykorzystania kapitałów własnych oraz kondycji finansowej spółki; (5) brak uwzględnienia czynnika czasu. Szczegółowe omówienie przedstawionych wad zostało przedstawione w: J. Jeżak, Ład korporacyjny. Doświadczenia światowe oraz kierunki rozwoju, C.H. Beck, Warszawa 2010, s. 99-101 oraz A. Rappaport, Wartość dla akcjonariuszy. Poradnik menedżera i inwestora, WIG-Press, Warszawa 1999, s. 15-35.

${ }^{2}$ J. Jeżak, Ład korporacyjny..., s. 114.

${ }^{3}$ K. Pniewski, B. Bartoszewicz, Kreowanie wartości jako cel nadrzędny, [w:] A. Szablewski, K. Pniewski, B. Bartoszewicz (red.), Value Based Management. Koncepcje, narzędzia, przykłady, Poltext, Warszawa 2008, s. 53.

${ }^{4}$ Ibidem, s. 62. 
1) W jaki sposób mierzyć tworzenie wartości?

2) W jaki sposób sformułować i komunikować strategię wzrostu wartości firmy?

3) W jaki sposób dokonać integracji celów i strategii wzrostu wartości z systemem zarządzania efektywnością firmy? Jak zarządzać realizacją strategii wzrostu wartości?

4) W jaki sposób motywować kadrę pracowniczą do podnoszenia wartości?

W ramach pierwszego obszaru systemu VBM należy wyznaczyć jeden konkretny i mierzalny cel, który będzie odzwierciedlał aspiracje firmy związane z zapewnieniem maksymalnego zwrotu dla akcjonariuszy, przy równoczesnym uwzględnieniu interesów pozostałych interesariuszy (tj. klientów, pracowników, społeczności lokalnej, środowiska naturalnego, dostawców oraz kredytodawców). Cel ten powinien być również możliwy do kaskadowania na niższe szczeble zarządzania $\mathrm{w}$ późniejszych etapach związanych z procesem implementacji strategii, aby umożliwić pracownikom wzięcie odpowiedzialności za swoje działania, a tym samym przyczynić się do zwiększenia zaangażowania w ramach realizowanych przez nich inicjatyw.

W ramach drugiego obszaru systemu VBM należy opracować strategię, czyli tzw. spójną koncepcję działania („plan gry”), która umożliwi przedsiębiorstwu osiągnięcie przewagi konkurencyjnej na rynku. Zdaniem J.B. Barneya oraz W.S. Hesterlya firma może osiągnąć przewagę konkurencyjną, jeżeli przy danych zasobach jest w stanie wygenerować lepsze wyniki ekonomiczne (mierzone m.in. poprzez porównanie osiągniętej stopy zwrotu $\mathrm{z}$ zaangażowanego kapitału z jego kosztem) aniżeli jej konkurenci ${ }^{5}$. Trafnie podsumował tę kwestię T. Dudycz, zdaniem którego „przewaga konkurencyjna odróżnia przedsiębiorstwo od konkurencji i dzięki temu może ono osiągać większy zwrot dla akcjonariuszy. Ma ona znaczenie w tworzeniu wartości, jeżeli prowadzi do wyższej ceny, niższych kosztów, większej sprzedaży itd." $\mathrm{W}$ związku z powyższym na proces formułowania strategii składają się trzy kluczowe etapy ${ }^{7}$ :

1) identyfikacja oczekiwań inwestorów oraz analiza strategiczna dotycząca możliwości budowania wartości firmy;

2) zdefiniowanie możliwych scenariuszy wzrostu wartości oraz wybór optymalnego wariantu;

3) dopracowanie wybranego scenariusza do postaci strategii wzrostu wartości, która zawiera rozłożenie nadrzędnego celu wzrostu na cele cząstkowe oraz identyfikacja inicjatyw strategicznych, które mogą zmienić kierunek działań firmy.

${ }^{5}$ J.B. Barney, W.S. Hesterly, Strategic management and competitive advantage. Concepts and cases, Prentice Hall, $4^{\text {th }}$ edition, New Jersey 2011, s. 42-43.

${ }^{6}$ T. Dudycz, Zarzadzanie wartościa przedsiębiorstwa, PWE, Warszawa 2005, s. 31.

${ }^{7}$ W. Gorzeń, K. Piernicki, K. Pniewski, Formułowanie i komunikacja strategii wzrostu wartości, [w:] A. Szablewski, K. Pniewski, B. Bartoszewicz (red.), Value Based Management..., s. $110-111$. 


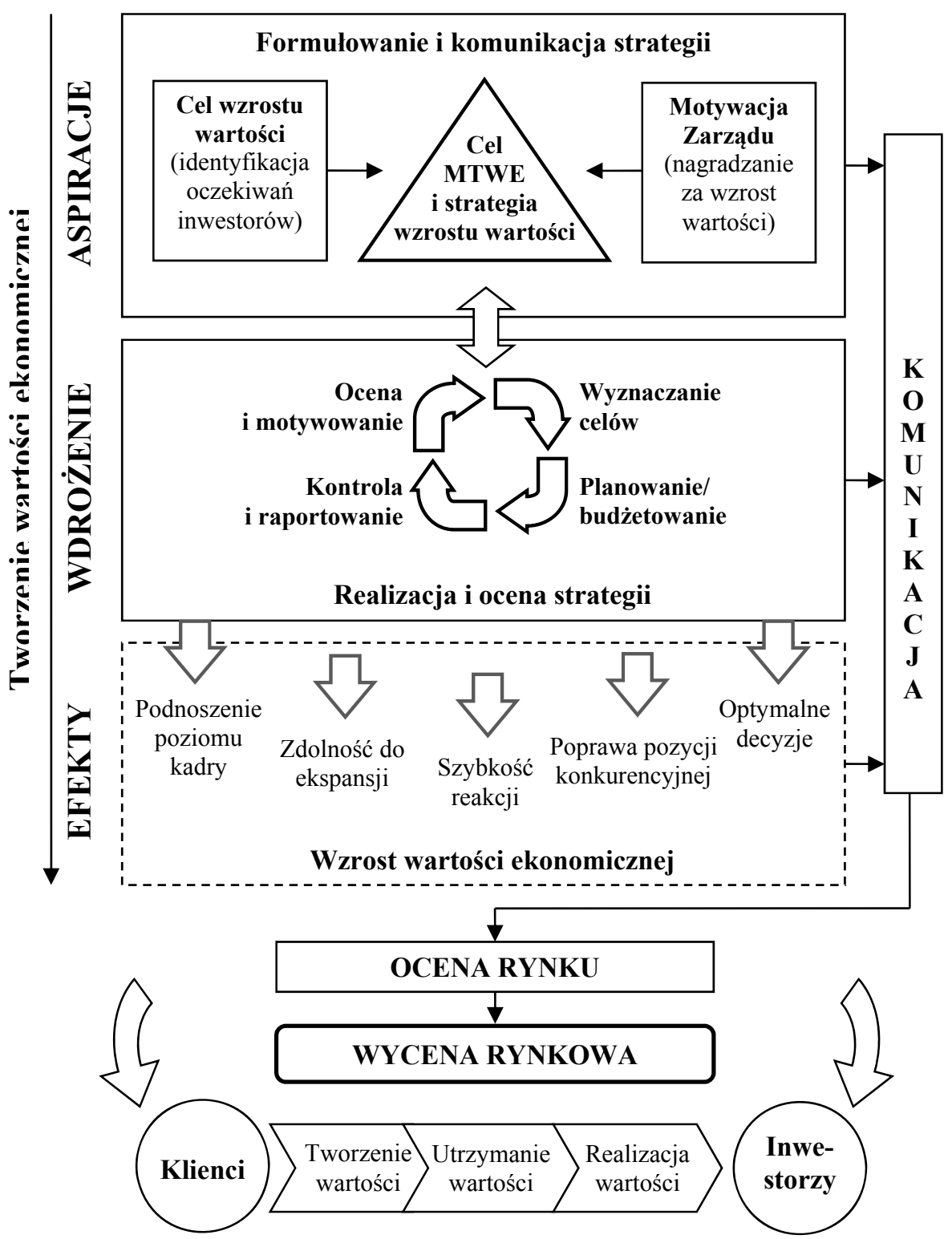

Rysunek 1. Schemat systemu zarządzania wartością firmy

Źródło: K. Pniewski, B. Bartoszewicz, Kreowanie wartości jako cel nadrzędny, [w:] A. Szablewski, K. Pniewski, B. Bartoszewicz (red.), Value Based Management-koncepcje, narzędzia, przykłady, Poltext, Warszawa 2008, s. 57 (modyfikacje własne); P. Szczepankowski, Wycena i zarządzanie wartościa przedsiębiorstwa, Wydawnictwo Naukowe PWN, Warszawa 2007, s. 30. 
Ze względu na fakt, iż każdą strategię trzeba wyjaśnić sporej grupie interesariuszy (m.in. pracownikom, dostawcom, obecnym oraz potencjalnym inwestorom), należy wziąć pod uwagę, aby była ona stosunkowo prosta (powinna dać się rozrysować na jednej kartce papieru - im więcej aspektów traktowane jest w firmie jako kluczowe, tym trudniej o ich spójne połączenie) oraz charakteryzowała się jednoznacznością kluczowych wyborów i celów ${ }^{8}$.

Mimo, że strategia może być stosunkowo prosta, nie musi to oznaczać, że jej implementacja będzie łatwa. Kluczem do sukcesu na tym etapie jest jej rygorystyczne wdrożenie na poziomie operacyjnym ${ }^{9}$, natomiast wśród najczęściej wykorzystywanych narzędzi można wyróżnić Strategiczną Kartę Wyników (która umożliwia dopracowanie i wyjaśnienie pracownikom wizji i strategii przedsiębiorstwa, planowanie i wyznaczanie celów, a także monitorowanie realizacji strategii oraz uczenie $\operatorname{sie}^{10}$ ), plany dziedzinowe oraz budżety.

W końcu nie należy zapominać o systemie motywacyjnym, który powinien stanowić integralną część systemu zarządzania wartością firmy. Eksperci w zakresie koncepcji VBM podkreślają, że kreowanie wartości rozpoczyna się już na samym dole hierarchii organizacyjnej, a docelowo „ma spowodować, aby wszyscy członkowie organizacji zaczęli myśleć i postępować tak, jak jej właściciele, mając, dzięki programowi motywacyjnemu, w tym swój osobisty interes"11 - pracownicy są bowiem wynagradzani adekwatnie do ich wkładu w budowanie wartości, co z kolei implikuje podejmowanie lepszych decyzji, wzrost dyscypliny oraz efektywności ich pracy ${ }^{12}$.

\section{Ekonomiczna wartość dodana jako miernik tworzonej wartości}

Nieodzownym elementem każdego systemu VBM jest miernik tworzenia wartości ekonomicznej (zwany również miernikiem kreowanej wartości lub miernikiem okresowych wyników działalności), który powinien zintegrować oczekiwania inwestorów działających na rynkach kapitałowych z perspektywą kadry menedżerskiej odpowiedzialnej za wyniki przedsiębiorstwa, a przy tym stanowi centralne narzędzie zarządcze odzwierciedlające wszystkie wymiary mające istotne znaczenie dla zwiększania wartości firmy ${ }^{13}$. Miernik, stanowiący

\footnotetext{
${ }^{8}$ K. Obłój, Pasja i dyscyplina strategii. Jak z marzeń $i$ decyzji zbudować sukces firmy, Poltext, Warszawa 2010, s. 170-172.

${ }^{9}$ Ibidem, s. 167.

${ }^{10}$ R.S. Kaplan, D.P. Norton, Strategiczna karta wyników. Jak przełożyć strategię na działanie, Wydawnictwo Naukowe PWN, Warszawa 2001, s. 30.

${ }_{11}$ A. Cwynar, K. Zawadzki, I. Kliś, B. Bielak, K. Sowińska-Bonder, Wdrażanie systemu VBM, [w:] A. Cwynar, P. Dżurak (red.), Systemy VBM i zysk ekonomiczny, Poltext, Warszawa 2010, s. 239.

${ }^{12}$ T. Dudycz, Zarzadzanie wartościa..., s. 35.

13 A. Ehrbar, EVA. Strategia tworzenia wartości przedsiębiorstwa, WIG-Press, Warszawa 2000, s. 1.
} 
szkielet koncepcji VBM, powinien przede wszystkim umożliwiać sprawne zarządzanie kapitałem, zwiększanie przychodów oraz kontrolę kosztów, a przez to spełniać swoją funkcję na pograniczu czterech obszarów związanych z: pomiarem okresowych wyników działalności, oceną opłacalności projektów inwestycyjnych, wdrożeniem system motywacyjnego oraz wyceną przedsiębiorstwa (por. rysunek 2).

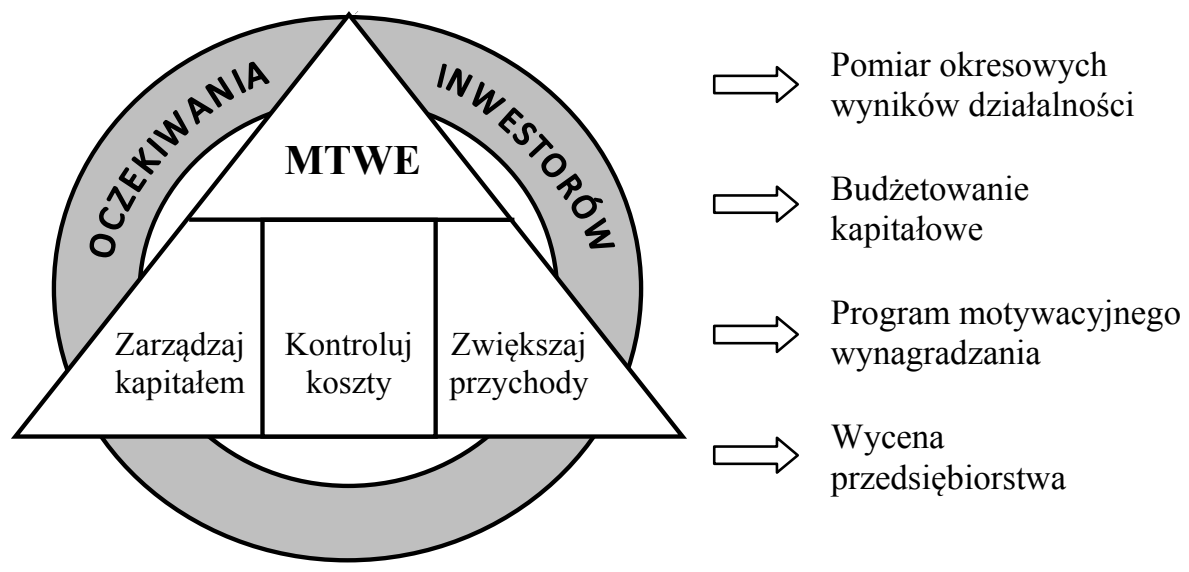

Rysunek 2. Rola miernika tworzenia wartości ekonomicznej w koncepcji VBM

Źródło: opracowanie własne na podstawie: K. Pniewski, B. Bartoszewicz, Pomiar tworzonej wartości w systemie zarządzania wartościa, [w:] A. Szablewski, K. Pniewski, B. Bartoszewicz (red.), Value Based Management..., s. 70; A. Cwynar, VBM jako system kontroli menedżerskiej - geneza, istota, kondycja, [w:] A. Cwynar, P. Dżurak P. (red.), Systemy VBM i zysk ekonomiczny, Poltext, Warszawa 2010, s. 56.

Koncepcją najbardziej rozpowszechnioną w zakresie pomiaru tworzonej wartości, a jednocześnie wzbudzającą sporo kontrowersji w środowisku akademickim, jest ekonomiczna wartość dodana (economic value added $-\mathrm{EVA}^{\mathbb{B 1 4}}$ ), której podstawą kalkulacji jest koncepcja zysku rezydualnego (zwanego również zyskiem ekonomicznym) rozumianego jako nadwyżka wypracowanego wyniku operacyjnego po opodatkowaniu ponad koszt kapitału przedsiębiorstwa. Zasadniczą przewagą ekonomicznej wartości dodanej nad zyskiem księgowym jest uwzględnienie kosztu kapitału własnego, który stanowi minimalną akceptowalną stopę zwrotu z inwestycji kapitałowej. Często kategoria ta określana jest mianem kosztu utraconych korzyści, ponieważ szacowana jest jako stopa zwrotu $\mathrm{z}$ alternatywnych inwestycji dostępnych dla inwestorów na rynku, które charakteryzują się podobnym ryzykiem. W związku z powyższym firma kreuje wartość

14 Koncepcja opracowana i zastrzeżona przez amerykańską firmę konsultingową Stern Stewart \& Co. 
dla inwestorów, jeżeli potrafi zarobić więcej niż wynosi jej koszt kapitału wyrażony w jednostkach pieniężnych ${ }^{15}$.

Podstawową formułę umożliwiająca kalkulację EVA można przedstawić za pomocą dwóch ekwiwalentnych postaci ${ }^{16}$ :

$$
\begin{aligned}
& E V A_{t}=N O P A T_{t}-I C_{t B E G} \times W A C C_{t} \\
& E V A_{t}=\left(R O I C_{t}-W A C C_{t}\right) \times I C_{t B E G}
\end{aligned}
$$

gdzie:

NOPAT - zysk operacyjny po opodatkowaniu (net operating profit after tax),

IC - kapital zainwestowany (invested capital),

ROIC - stopa zwrotu z zainwestowanego kapitału (return on invested capital),

$W A C C$ - średnioważony koszt kapitału (weighted average cost of capital),

$t_{B E G} \quad-$ początek okresu pomiaru,

$t \quad-$ okres pomiaru.

Zastosowany w powyższym wzorze NOPAT stanowi ,wynik finansowy osiągnięty na podstawowej działalności operacyjnej przedsiębiorstwa, pomniejszony o amortyzację oraz o podatek, jaki zostałby przez nie zapłacony, gdyby zredukować je wyłącznie do tej działalności"17. Z kolei zainwestowany kapitał stanowi ,środki zaangażowane w podstawową działalność operacyjną przedsiębiorstwa, dzięki którym został osiągnięty zysk NOPAT" ${ }^{18}$. W końcu WACC stanowi średnią z kosztów kapitału własnego i obcego, która została zważona udziałami każdego z kapitałów w stosunku do ich sumy.

Dotychczas zaprezentowana koncepcja ekonomicznej wartości dodanej odnosi się jednak tylko i wyłącznie do firm działających w sektorze pozafinansowym. Niemniej, istnieje możliwość jej zaadaptowania do specyfiki sektora bankowego (który różni się od przedsiębiorstw z sektora pozafinansowego przede wszystkich charakterem działalności oraz związanym z nim odmiennym schematem budowy sprawozdań finansowych). Wówczas tzw. bankowa ekonomiczna wartość dodana zostanie opisana formułą ${ }^{19}$ :

${ }^{15}$ R.A. Brealey, S.C. Myers., F. Allen, Principles of Corporate Finance, McGraw-Hill/Irwin, $10^{\text {th }}$ edition, New York 2011, s. 709.

${ }^{16}$ T. Koller, M. Goedhart, D. Wessels, Valuation. Measuring and Managing the Value of Companies, John Wiley \& Sons, $5^{\text {th }}$ edition, New Jersey 2010, s. 117.

17 A. Cwynar, Wycena przedsiębiorstwa metoda zdyskontowanych zysków ekonomicznych (EVA), [w:] M. Panfil, A. Szablewski (red.), Wycena przedsiębiorstwa. Od teorii do praktyki, Poltext, Warszawa 2011, s. 363.

${ }^{18}$ Ibidem.

${ }^{19}$ D. Siudak, Wybrane aspekty ekonomicznej wartości dodanej w bankowości, [w:] D. Zarzecki (red.), Zarzadzanie finansami. Inwestycje $i$ wycena przedsiębiorstw, t. 1, Wydział Nauk Ekonomicznych i Zarządzania Uniwersytetu Szczecińskiego, Szczecin 2006, s. 548. Szczegółowe 


$$
B E V A=B O P \times(1-T)-k_{e} \times K_{E(B E G)}
$$

gdzie:

$B O P$ - bankowy zysk operacyjny,

$T$ - stopa podatku dochodowego od osób prawnych,

$k_{e} \quad-$ koszt kapitału własnego,

$K_{E(B E G)}$ - księgowa wartość kapitału własnego na początku badanego okresu.

Następnie dokonując przekształceń matematycznych, wskaźnik BEVA oraz wskaźnik rentowności kapitału własnego oparty na bankowym zysku operacyjnym po opodatkowani $\left(R O E_{B O P}\right)$ można przedstawić w następujący sposób ${ }^{20}$ :

$$
\begin{gathered}
B E V A=\left(\frac{B O P \times(1-T)}{K_{E}}-k_{e}\right) \times K_{E(B E G)} \\
R O E_{B O P}=\frac{B O P \times(1-T)}{K_{E(B E G)}}
\end{gathered}
$$

co z kolei umożliwia sprowadzenie BEVA do postaci:

$$
B E V A=\left(R O E_{B O P}-k_{e}\right) \times K_{E(B E G)}
$$

Interpretacja bankowej wartości dodanej jest identyczna, jak w przypadku przedsiębiorstw niefinansowych - spółka kreuje wartość dla akcjonariuszy, gdy rentowność operacyjna zainwestowanego kapitału jest wyższa aniżeli koszt kapitału.

\section{Opis badania}

Badaniu poddane zostało 12 banków notowanych na Warszawskiej Giełdzie Papierów Wartościowych, które w latach 2003-2012 wchodziły w skład indeksu WIG-Banki. Na podstawie danych finansowych opublikowanych w serwisach: notoria.pl, money.pl, bankier.pl oraz stooq.pl obliczona została bankowa ekonomiczna wartość dodana generowana przez każdy z badanych podmiotów, a następnie - w celu oszacowania efektywności działania - zbadana została

omówienie różnic w budowie sprawozdań finansowych dla przedsiębiorstw spoza sektora finansowego oraz dla banków, a także implikacje z tego wynikające dla kalkulacji ekonomicznej wartości dodanej można znaleźć w: D. Siudak, Wybrane aspekty..., s. 547-548.

${ }^{20}$ Ibidem, s. 548-549. 
relacja tworzonej wartości w stosunku do kapitału zainwestowanego w każdy z banków oraz korelacja pomiędzy ekonomiczną wartością dodaną wypracowaną w okresie każdego roku a roczną stopą zwrotu z akcji.

Do obliczenia bankowej ekonomicznej wartości dodanej wykorzystano wzór prezentowany na łamach niniejszego artykułu. Bankowy zysk operacyjny oraz wartość księgowa kapitału własnego zostały pobrane z bazy danych dostępnej w serwisie notoria.pl. W przypadku wystąpienia braków - wśród opublikowanych danych finansowych, zostały one uzupełnione o stosowne informacje opublikowane przez serwisy bankier.pl oraz money.pl. Koszt kapitału własnego został oszacowany w oparciu o model wyceny aktywów kapitałowych (capital assets pricing model - CAPM), który określony jest wzorem ${ }^{21}$ :

$$
k_{e}=r_{f}+\beta \times\left(r_{m}-r_{f}\right)
$$

gdzie:

$k_{e}$ - koszt kapitału własnego,

$r_{f}$ - stopa zwrotu wolna od ryzyka,

$\beta$ - indeks ryzyka rynkowego firmy,

$r_{m}$ - stopa zwrotu z rynku ogółem.

Jako stopę zwrotu $\mathrm{z}$ aktywów wolnych od ryzyka przyjęto średnią stopę zwrotu z 52-tygodniowych bonów skarbowych ${ }^{22}$. Indeks ryzyka rynkowego firmy $^{23}$ (współczynnik $\beta$ ) został wyznaczony z wykorzystaniem analizy regresji dostępnej $\mathrm{w}$ arkuszu kalkulacyjnym MS Excel, gdzie do obliczeń przyjęto tygodniowe stopy zwrotu $\mathrm{z}$ akcji badanych podmiotów oraz tygodniowe stopy zwrotu z rynku ogółem reprezentowanego przez indeks $\mathrm{WIG}^{24}$. Z kolei premia za ryzyko (czyli różnica pomiędzy stopą zwrotu z rynku ogółem a stopą zwrotu wolną od ryzyka) została przyjęta na powszechnie stosowanym przez analityków poziomie $5 \%$.

Ze względu na fakt, iż analizowane banki dysponują kapitałem własnym na bardzo zróżnicowanym poziomie, nieuzasadnione byłoby bezpośrednie porównanie wytworzonych przez nie zysków ekonomicznych. W związku z powyższym, jako miarę oceny efektywności budowania wartości przyjęto relację bankowej ekonomicznej wartości dodanej do zainwestowanego kapitału (w tym przypadku tożsamego $\mathrm{z}$ wartością księgową kapitału własnego) na początku każdego badanego okresu.

${ }^{21}$ W. Cwynar, Koszt kapitału własnego jako szczególna zmienna $w$ rachunku zysku ekonomicznego, [w:] A. Cwynar, P. Dżurak (red.), Systemy VBM..., s. 155.

${ }^{22}$ Dane pozyskane z serwisu bankier.pl.

${ }^{23}$ Obliczany jako iloraz kowariancji rentowności akcji badanego przedsiębiorstwa $j$ oraz rynku $m$ i wariancji rentowności rynku $m$.

${ }^{24}$ Dane pozyskane z serwisu stooq.pl. 
Ostatnia część badania dotyczy związku pomiędzy bankową ekonomiczną wartością dodaną wytworzoną przez banki a roczną stopą zwrotu z ich akcji. Do badania powyższej zależności wykorzystana została analiza korelacji za pomocą dodatku Analysis ToolPak wchodzącego w skład arkusza kalkulacyjnego MS Excel.

\section{Uzyskane wyniki}

W analizowanym okresie najwyższą wartość dla inwestorów wypracowały kolejno banki: PKO BP (1,2 mln zł), PEKAO (0,85 mln zł) oraz BZ WBK $(0,41 \mathrm{mln} \mathrm{z})$. Te same podmioty charakteryzowały się również najwyższym poziomem efektywności działania mierzonym relacją BEVA do kapitału zainwestowanego (na poziomie 7-9\%), choć w tym przypadku bardzo dobre wyniki uzyskał również BRE Bank (8\%). Wśród spółek, które - biorąc pod uwagę wyniki średnioroczne - przyczyniły się do destrukcji wartości dla akcjonariuszy, można wskazać: BNP Paribas ( $-41 \mathrm{mln} \mathrm{z})$, Bank BPH $(-34,5 \mathrm{mln} \mathrm{zl})$ oraz Bank Ochrony Środowiska ( $-14 \mathrm{mln}$ zł). Pełne zestawienie średnich wyników na lata 2003-2012 przedstawiono na rysunku 3.

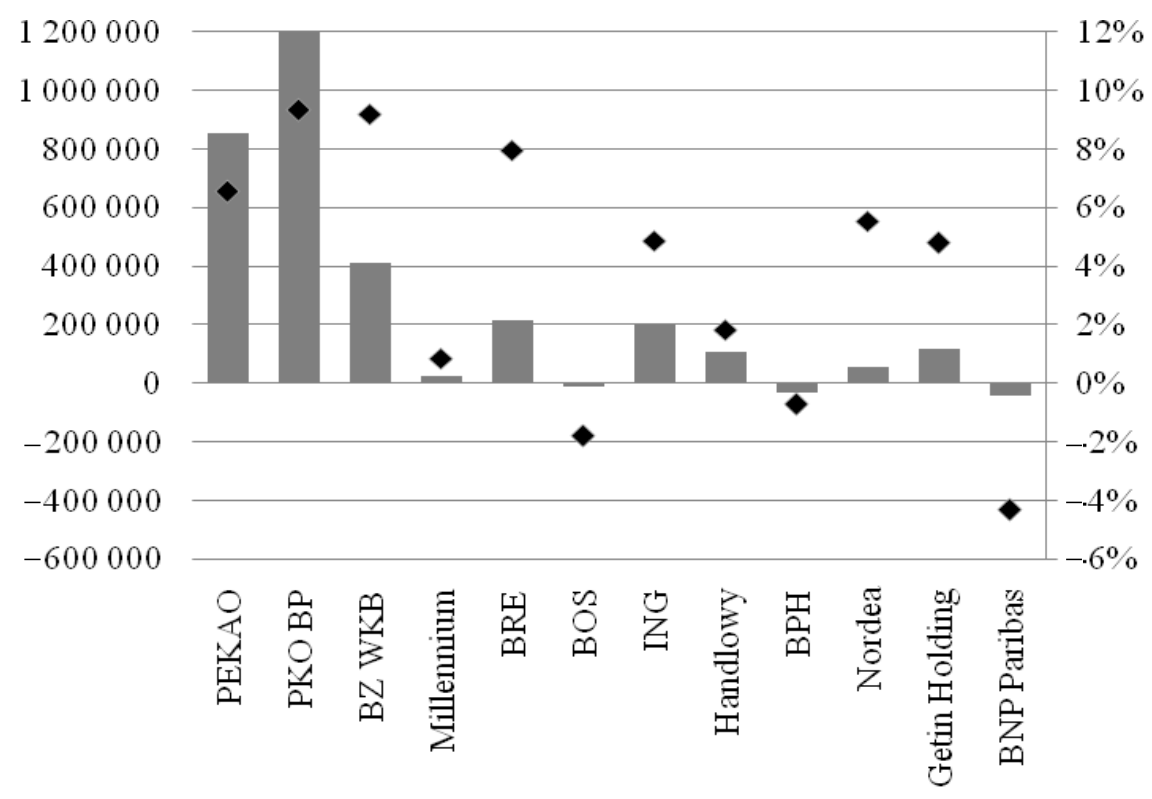

- ŚredniaBEVA w tys. PLN w latach 2003-2012 (skala lewa)

- ŚredniaBEVA/IC w latach 2003-2012 (skala prawa)

Rysunek 3. Średnia BEVA oraz BEVA/IC dla banków w latach 2003-2012 Źródło: opracowanie własne. 
Biorąc pod uwagę ekonomiczną wartość dodaną wytworzoną w roku 2012, do liderów zaliczyć można te same banki, które uzyskały najlepsze wyniki średnie za ostatnie 10 lat, chociaż pod względem efektywności mierzonej relacją BEVA/IC najlepsze wyniki wypracowały: BRE Bank (14,7\%), BZ WBK (9,5\%) oraz Bank Handlowy (6,8\%). Z kolei do banków, które charakteryzowały się najniższą efektywnością działania, zaliczyć można te same, które osiągnęły najgorsze wyniki w okresie ostatnich 10 lat. Pełne zestawienie wyników za ostatni rok zostało zaprezentowane na rysunku 4.

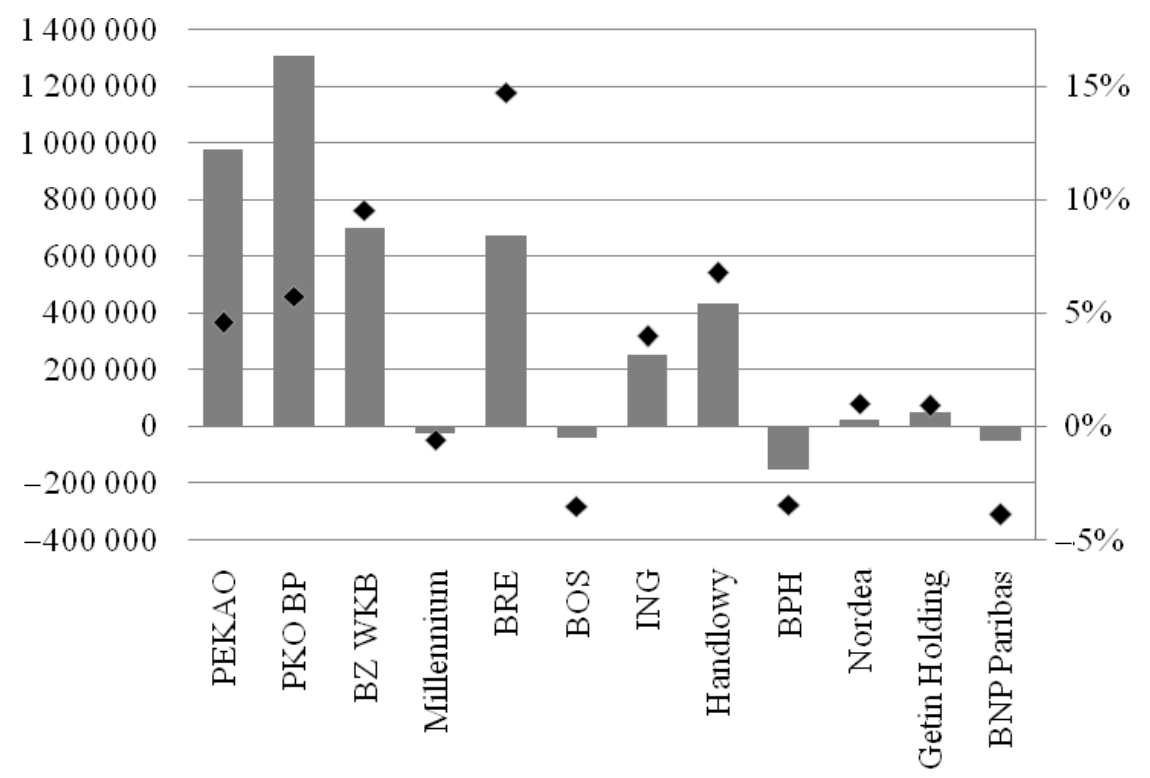

- BEVA w tys. PLN w roku 2012 (skala lewa)

- BEVA/IC w roku 2012 (skala prawa)

Rysunek 4. BEVA oraz BEVA/IC dla banków w roku 2012

Źródło: opracowanie własne.

Zdaniem B. Stewarta, ekonomiczna wartość dodana poddana stosownym korektom $^{25}$ wykazuje korelację $\mathrm{z}$ wyceną giełdową na poziomie $60-80 \%{ }^{26}$. Kwestia ta budzi jednak wiele kontrowersji, zwłaszcza w środowisku akademickim.

\footnotetext{
${ }^{25}$ Firma doradcza Stern Stewart \& Co. Zidentyfikowała ponad 160 korekt księgowych wykorzystywanych przy obliczaniu EVA w zależności od analizowanej branży, jednak ze względu na pracochłonność oraz trudności związane $\mathrm{z}$ ich zastosowaniem, w praktyce wykorzystuje się tylko od kilku do kilkunastu korekt.

${ }^{26}$ Zapis wywiadu z Bennettem Stewartem z 01.02.1996 r. Zob.: http://home.snc.edu/ eliotelfner/333/eva_5.htm (dostęp 30.06.2013).
} 
Tabela 1. Korelacja między bankową roczną ekonomiczną wartością dodaną a roczną stopą zwrotu z akcji w latach 2003-2012

\begin{tabular}{|c|c|c|c|c|c|c|}
\hline Nazwa banku & PEO & PKO & BZW & MIL & BRE & BOS \\
\hline $\begin{array}{c}\text { Współczynnik } \\
\text { korelacji }\end{array}$ & $-0,5903$ & $-0,3821$ & $-0,0637$ & 0,0907 & $-0,1910$ & 0,4026 \\
\hline Nazwa banku & ING & BHW & BPH & NDA & GTN & BNP \\
\hline $\begin{array}{c}\text { Współczynnik } \\
\text { korelacji }\end{array}$ & 0,3238 & 0,4845 & 0,0754 & 0,0688 & $-0,4903$ & 0,2154 \\
\hline
\end{tabular}

Źródło: opracowanie własne.

W związku z powyższym, autor niniejszego artykułu postanowił przeprowadzić wstępne badanie, które miało na celu porównanie związku pomiędzy ekonomiczną wartością dodaną generowaną przez poszczególne banki w okresie rocznym oraz roczną stopą zwrotu $\mathrm{z}$ akcji danej spółki, którą mogli uzyskać inwestorzy (por. tabela 1). Niestety uzyskane rezultaty są niejednoznaczne ${ }^{27}$ - wśród badanych banków występowała zarówno korelacja dodatnia (7 podmiotów), jak i ujemna ( 5 podmiotów) o sile związków na poziomie niskim (3 banki) bądź umiarkowanym (4 banki). Zasadne wydaje się więc dokonanie pogłębionego badania, które będzie opierało się na większej liczbie spółek.

\section{Zakończenie}

Przeprowadzone w ramach artykułu analizy wykazały, iż większość badanych banków była na tyle dobrze zarządzana, iż przyczyniła się do wzrostu kreowanej wartości dla akcjonariuszy nawet pomimo kryzysu finansowego (i związanego z nim spadku zaufania do instytucji bankowych), który w ostatnich latach odcisnął swoje piętno nie tylko na amerykańskiej gospodarce czy w krajach strefy euro, ale również w Polsce. W latach 2003-2012 badane spółki wypracowały łącznie niemal $31 \mathrm{mld}$ zł zysku ekonomicznego, z czego ponad 12,5 mld zł przypadło na ostatnie 3 lata.

Wydaje się, że w związku z rosnącym w Polsce zainteresowaniem tematyką zarządzania wartością spółek oraz faktem, iż w kraju tym systemy VBM dopiero zaczynają być poznawane i wdrażane, istnieje wciąż znaczny potencjał do poprawy wyników osiąganych przez przedsiębiorstwa. Warto jednak pamiętać, że mierniki tworzenia wartości ekonomicznej (w tym przedstawiona ekonomiczna wartość dodana) nie mogą pozostawać celem samym w sobie - muszą stanowić one podstawę wdrożenia kompleksowego systemu, dzięki któremu zarząd powinien lepiej rozumieć, jakie czynniki są kluczowe dla budowania wartości firmy oraz czego oczekiwać i w jaki sposób motywować swoich pracowników do wspólnego wysiłku, którego efektem będzie wzrost wartości firmy.

\footnotetext{
${ }^{27}$ Co zapewne wynika również z niewielkiej próby przyjętej do badania.
} 


\section{Literatura}

Barney J.B., Hesterly W.S., Strategic Management and Competitive Advantage. Concepts and Cases, Prentice Hall, $4^{\text {th }}$ edition, New Jersey 2011.

Brealey R.A, Myers S.C., Allen F., Principles of Corporate Finance, McGraw-Hill/Irwin, $10^{\text {th }}$ edition, New York 2011.

Cwynar A., Dżurak P. (red.), Systemy VBM i zysk ekonomiczny, Poltext, Warszawa 2010.

Dudycz T., Zarządzanie wartościa przedsiębiorstwa, PWE, Warszawa 2005.

Ehrbar A., EVA. Strategia tworzenia wartości przedsiębiorstwa, WIG-Press, Warszawa 2000.

Jeżak J., Ład korporacyjny. Doświadczenia światowe oraz kierunki rozwoju, C.H. Beck, Warszawa 2010.

Kaplan R.S., Norton D.P., Strategiczna karta wyników. Jak przełożyć strategię na dziatanie, Wydawnictwo Naukowe PWN, Warszawa 2001.

Koller T., Goedhart M., Wessels D., Valuation. Measuring and managing the value of companies, John Wiley \& Sons, $5^{\text {th }}$ edition, New Jersey 2010.

Obłój K., Pasja i dyscyplina strategii. Jak z marzeń i decyzji zbudować sukces firmy, Poltext, Warszawa 2010.

Panfil M., Szablewski A., Wycena przedsiębiorstwa. Od teorii do praktyki, Poltext, Warszawa 2011.

Rappaport A., Wartość dla akcjonariuszy. Poradnik menedżera i inwestora, WIG-Press, Warszawa 1999.

Siudak D., Wybrane aspekty ekonomicznej wartości dodanej w bankowości [w:] Zarzecki D. (red.), Zarządzanie finansami. Inwestycje $i$ wycena przedsiębiorstw, t. 1, Wydział Nauk Ekonomicznych i Zarządzania Uniwersytetu Szczecińskiego, Szczecin 2006.

Szablewski A., Pniewski K., Bartoszewicz B. (red.), Value Based Management. Koncepcje, narzędzia, przyklady, Poltext, Warszawa 2008.

Szczepankowski P., Wycena i zarządzanie wartościa przedsiębiorstwa, Wydawnictwo Naukowe PWN, Warszawa 2007.

http://home.snc.edu/eliotelfner/333/eva_5.htm.

www.bankier.pl.

www.money.pl.

www.notoria.pl.

www.stooq.pl.

\section{Streszczenie}

Głównym celem artykułu jest przedstawienie roli ekonomicznej wartości dodanej $(E V A \circledast)$ w koncepcji zarządzania wartością firmy oraz zbadanie poziomu kreowanej wartości wśród 12 banków notowanych na Giełdzie Papierów Wartościowych w Warszawie w okresie ostatnich 10 lat.

\section{Summary}

\section{EVA AS A KEY ELEMENT OF STRATEGY ORIENTED ON VALUE MAXIMIZATION - ANALYSIS OF THE POLISH BANKING SECTOR}

The main aim of the article is to present the role of economic value added (EVA®) in value-based management systems and to determine the level of the value created among 12 banks listed on Warsaw Stock Exchange during the last 10 years. 